\title{
Time and Tense in Language
}

\author{
Mohammad Jafar Jabbari \\ Faculty of Literature \& Humanities, Yasouj University, Yasouj, Iran \\ Tel: 98-917-141-1227Ｅ-mail: mjjabbari@mail.yu.ac.ir
}

Received: January 19, 2013 Accepted: February 18, 2013 Published: October 28, 2013

doi:10.5296/ijl.v5i5.4518ＵRL: http://dx.doi.org/10.5296/ijl.v5i5.4518

\begin{abstract}
"Tense" is a linguistic phenomenon, whereas "time" is an extra-linguistic concept. Tense is the grammatical category which correlates with distinctions of time. Every language is capable of expressing events happening in different times. Differentiating between time and tense in language is far from trivial. It has proved to play an important part in language learning and translation. By scrutinizing the time-tense dichotomy, this article aims to show that there is no one-to-one correspondence between time and tense, both intra- and inter-lingually and also to show how this is so essential in language learning and translation.
\end{abstract}

Keywords: Tense, Time, Referring time, Event time 


\section{Introduction}

Languages are capable of expressing events happening in different times. Many languages, referred to as 'tense languages', build a number of time distinctions into their grammars. Thus, tense is said to be the 'grammaticalization' of time. One important thing which should be clarified is the essential difference between time and tense; tense is a grammatical category, whereas time is an extra-linguistic universal concept. This has resulted in the fact that there is no one-to-one correspondence between time and tense, within a certain language, on the one hand, and between different languages, on the other. The recognition of the time-tense dichotomy plays a crucial role in language learning and translation. This article aims to shed light on differences between time and tense, especially in English and Persian, for the purpose of facilitating teaching English to Iranian EFL learners.

\section{Background}

\subsection{Time}

Klein (1994) maintains that "time and space are basic categories of our experience and our cognition...Therefore, all natural languages we know of have developed a rich repertoire of means to express temporality and spatiality" (p.1). He argues that "the verb not only expresses an event, an action, process, etc., but it also links whatever it expresses to particular times. Three such times are normally distinguished, according to their relation to the present moment: past, present, future. Aristotle, who was the first to discuss tense variation of the verb, indeed only referred to these three times (Peri hermeneias, 16 b)" (p. 18).

For Jespersen (1924), time is a natural or notional concept which in many languages is expressed in tenses.

Time is "a universal, non-linguistic concept with three divisions: past, present and future; by tense we understand the correspondence between the form of a verb and our concept of time"(Quirk \& Greenbaum, 1973, p.40).

\subsection{Tense}

Making a distinction between form and function in analyzing tense dates back to ancient Greece. "A more significant advance made by Aristotle was his recognition of the category of tense in the Greek verb: that is to say, he noted that certain semantic variations in the forms of the verb could be correlated with such temporal notions as 'present' or 'past. His teaching on this point, however (though more explicit than Plato's), is far from clear"(Lyons, 1968, p. 11 , focus added).

The International Encyclopedia of Linguistics (1992, entry 'Tense, aspect and mood') elaborates tense as follows:

TENSE "refers to the grammatical expression of the time of the situation described in the proposition, relative to some other time. This other time may be the moment of speech: e.g., the PAST and Future designate time before the moment of speech, respectively.....TENSE is expressed by inflections, by particles, or by auxiliaries in 
connection with the verb.

The distinction is that "tense refers to the grammatical changes made to the form of a verb, as opposed to time, which refers to the semantic functions such changes signal"(Finch, 2005, p. 113).

"Tense shows the time of the action or state being expressed by a verb"(Shaw, 1986, p.110).

Tense is "the relationship between the form of the verb and the time of the action or state it describes"(Richards \& Schmidt, 2002, p 545).

Tense is the "inflectional category whose basic role is to indicate the time of an event, etc. in relation to the moment of speaking "(Matthews, 2007, p. 404).

Tense is "a grammatical category which involves changing the form of the verb to reflect the location of an event in time. The usual distinction is between past, present and future"(Baker, 2012, p. 304).

Tense is "the grammatical category which relates to time.....It is possible for a language to build a few of these time distinctions into its grammar, and a language which does so has the category of tense... Some languages lack tense entirely; an example is Chinese, which has nothing corresponding to the I go/I went contrast of English.” (Trask, 2008, p. 294)

As a rule tense is marked on verbs, though there are exceptions. "Some languages formally mark the expression of time relations on word classes other than the verb. In Japanese, adjectives can be marked in this way, e.g. shiroi 'white'. shirokatta 'was white, shirukute 'being white, etc."(Crystal, 1977, p. 92).

Comrie (1976) asserts that "the semantic concept of time reference (absolute or relative), ... may be grammaticalised in a language, i.e. a language may have a grammatical category that expresses time reference, in which case we say that the language has tenses. Some languages lack tense, i.e. do not have grammatical time reference, though probably all languages can lexicalise time reference, i.e. have temporal adverbials that locate situations in time" (p.6).

Comrie (1983) also maintains that "not all languages grammaticalise tense, and those that do differ in their grammaticalisation thereof. Languages without tense are called tenseless languages and include Burmese, Dyirbal and Chinese. Not all grammaticalise the three-way system of past-present-future" (p. 53).

"Tense is a factor in conjugation which refers to the time of an action described relative to the moment of description... The system of tense and aspect vary greatly from language to language" (Simpson, 184, p. xvi).

\subsection{Time-Tense Correspondence}

It is argued that there is not a perfect one-to-one relationship between time and tense.

Crystal (1977, p. 93), asserts that "Tense and time do not always correspond. Present tense-past time: Minister dies (headline), Present tense-future time: I'm leaving tomorrow". 
For Scovel (1971), one of the existing problems in the English language is that time and tense are not coterminous. He adds that languages have the idea of time i.e. past, present and future. They, however, differ in the linguistic form or the grammar of time.

Simpson (1984) asserts that "when tense is a grammatical category in a language, the number of members varies... Yet again the meaning of a tense may not be always that typically associates with it; English Did you want to go there? Is not necessarily past in meaning"(pp. 110-111).

For Radford (2006a) there is a time-tense correspondence, though it is not one-to-one. He puts it this way:

Tense correlates (to some extent) with time-reference, so that (e.g.) past-tense verbs typically describes an event taking place in the past, whereas present-tense verbs typically describe an event taking place in the present (or future). However, the correlation is an imperfect one, since e.g. in a sentence such as 'I might go there tomorrow', the auxiliary might carries the past-tense inflection $-t$ (found on past-tense main verbs like left) but does not denote past time. (p. 480).

\section{Data of the Study}

The data of the study are simple sentences, collected from elementary language text-books (Note 1). Simple sentences are deliberately chosen for the convenience of the discussions and argumentations.

\section{Discussions}

The above sentences imply that there is not a one-to-one correspondence between time and tense within any language. In other words, the same tense may be used for different time situations. Table (1) illustrates this lack of one-to-one correspondence between time and tense:

Table 1. Lack of lack of one-to-one correspondence between time and tense

\begin{tabular}{|c|c|c|c|}
\hline & Example & Tense & Time \\
\hline$(1)$ & I want a tea. & \multirow{3}{*}{$\begin{array}{l}\text { Preset } \\
\text { Simple }\end{array}$} & Present \\
\hline (2) & I leave tomorrow. & & Future \\
\hline (3) & I like tea. & & Past/Present/Future \\
\hline (4) & He is living in Tehran. & \multirow{3}{*}{$\begin{array}{r}\text { Present } \\
\text { Continuous }\end{array}$} & Past/Present/Future \\
\hline (5) & He is going to London now. & & Present \\
\hline (6) & He is going to London tomorrow. & & Future \\
\hline (7) & He has been to London, before. & \multirow{4}{*}{$\begin{array}{l}\text { Present } \\
\text { Perfect }\end{array}$} & Past \\
\hline (8) & He has finished. & & Present \\
\hline (9) & Prices have increased by $20 \%$. & & Past/Present \\
\hline (10) & I have always admired Shakespeare. & & Past/Present/Future \\
\hline
\end{tabular}




\begin{tabular}{|l|l|r|l|}
\hline$(11)$ & Hold on. I'll do it know & Future & Present \\
& & Simple & Future \\
\hline$(12)$ & I will see you tomorrow & Past & Present \\
& Could you please open the door & Simple & Past \\
& & & Future \\
\hline$(14)$ & I could not move. & I might see him tomorrow &
\end{tabular}

Examples (1) to (15) show how the same tense can be used to express different times.

It is worth noting that in some examples, like (2), (4), (6), (11), (12), (13) and (15) the tense are used optionally. However, sometimes, changing the tense is obligatory. Examples are conditionals, subjunctives and indirect speech in English.

Tense

(16) If I were rich, I would buy a bike.

(17) If I came tomorrow, I would see her.

(18) I wish I were in London now.

(19) He said that he was a professor.

\section{Past Simple}

Past Simple

Past Simple

Past Simple
Time

Present

Future

Present

Present

The verb was in Sentence (19), for example, undergoes a grammatical rule, referred to as the rule of "Sequence of Tenses" (Note 2). This rule, however, does not necessarily apply in all languages.

Lack of one-to-one correspondence holds true in other languages as well. In German, for example, there is only one present tense, which is used for two different time situations:

(20) Ich arbeite jetzt.

(21) Ich arbeite jedes Tag.
I am working now.

I work everyday.

In French, the tense "present indique" (indicative present) may be used to express different time situations:

(22) Il est étudiant.

(23) Il est malade aujoud'hui

(24) Il est en train de manger.

(25) Il travaille maintenent.

(26) Il travaille samedi.

(27) Il travaille le samedi.
$\mathrm{He}$ is a student.

He is sick today.

He is eating.

He is working now.

He works this Saturday.

He works every Saturday.

In Persian, the present tense may be used for different time situations. Consider the following example: 
(28) /mæn be tehran miræv-æm/

I to Tehran go-I

Sentence (28) can be interpreted as:

(29) I go to Tehran.

(30) I am going to Tehran

(31) I will go to Tehran.

The lack of one-to-one correspondence between time and tense is not one-sided. In other words, within any language, the same time situation may be expressed by different tenses. Table (2) illustrates how different tenses may express the same time:

Table 2. Different tenses for the same time

\begin{tabular}{|l|l|l|l|}
\hline & Example & Tense & Time \\
\hline (32) & She is making a speech next week & $\begin{array}{l}\text { Present } \\
\text { Continuous }\end{array}$ & \multirow{2}{*}{ Future } \\
\cline { 1 - 2 }$(33)$ & $\begin{array}{l}\text { The next meeting of the committee is on Nov. } \\
5^{\text {th }}\end{array}$ & Present Simple \\
\cline { 1 - 2 }$(34)$ & My train leaves for London in two hours. & Present Simple & \\
\cline { 1 - 2 }$(35)$ & My train will leave in two hours. & Future Simple & \\
\cline { 1 - 2 } & People are going to leave longer in future. & Future & \\
\hline
\end{tabular}

Examples (37) and (38) show the same situation in Persian:

(37) /mæn færda be tehran miræv-æm/

I tomorrow to Tehran go-I

(38) /mæn færda be tehran xahæm ræft/

I tomorrow to Tehran will go-infinitive
Present tense-Future time

Future tense-Future time

A typical example of no one-to-one relationship between time and tense is 'historic(al) present' tense. Historic present, also referred to as 'dramatic present' or 'narrative presents' is "a present tense used in contexts where a past tense would normally be used, to create a more vivid effect to show informality, or to show a sense of 'friendliness' between speaker and hearer. For example: Do you know what happened to me last night? I'm sitting in a restaurant when this guy comes up and pours water over me"(Richards \& Schmidt 2002, p. 240, focus added).

Historic(al) present is frequently used in many languages, especially in French:

(39) " Alphonse Daudet nait à Nimes le 13 mai 1890. Il fait ses études au lycée de Lyon mais ne peut les terminer......"(Daudet, 1997, p.3, focus added).

Alphonse Daudet is born at Nimes in May 1890. He does his studies at the high school of Lyon but he cannot finish it .......

In the following excerpt from Dickens' David Copperfield shifts from the past tense to the 
historic present tense are apparent:

(40)

If the funeral had been yesterday, I could not recollect it better. The very air of the best parlour, when I went in at the door, the bright condition of the fire, the shining of the wine in the decanters, the patterns of the glasses and plates, the faint sweet smell of cake, the odour of Miss Mudstone's dress, and our black clothes. Mr. Chillip is in the room, and comes to speak to me.

'And how is Master David?' he says, kindly. I cannot tell him very well. I give him my hand, which he holds in his. (Dickens, 1984, Chapter IX, focus added).

It is worthy of mention that although different tenses may be utilized to express the same time, the implied meaning may be different. Compare the following pair of sentences given by Hewings (2003):

(41) "She teaches math in a school in Bonn. (a permanent arrangement)

(42) She is teaching math in a school in Bonn. (implies that this is not, or may not be, permanent"(p. 2).

By the same token, in the following pair of sentences in Persian, different tenses are used for identical time:

(43) /diruz dær tehran bærf-i sængin. barid/ yesterday in Tehran snow-a heavy fell

Yesterday a heavy snow fell in Tehran.

(44) /diruz dær tehran bærf-i sængin barid-e (æst)/ yesterday in Tehran snow-a heavy fallen (is)

Yesterday a heavy snow has fallen in Tehran.

(43) and (44) though identical in time, due to benefiting from different tenses, have different tacit meanings. Sentence (43), but not (44) implies that the person uttering the sentence has been present in the place of the event, whereas sentence (44), but not (43) implies that the snow is still there.

The above examples illustrate the lack of one-to-one correspondence between time and tense intra-lingually.

On the other hand, there is no time-tense one-to-one correspondence inter-lingually. In other words, while time is a universal concept, the way of expressing time, i.e. tenses, may differ from language to language. Table (3) compares the tense in Persian with that of English. 


\section{Macrothink}

Table 3. A comparison of Persian and English tense

\begin{tabular}{|c|c|c|c|}
\hline & Persian & English & Time \\
\hline (45) & $\begin{array}{l}\text { Present Perfect } \\
\text { /'u xabide-'æst } \\
\text { (S)he slept is }\end{array}$ & $\begin{array}{l}\text { Present Continuous } \\
\text { (S)he is sleeping }\end{array}$ & Present \\
\hline (46) & $\begin{array}{l}\text { Present Perfect } \\
\text { /'u xabide-'æst } \\
\text { (S)he slept is }\end{array}$ & $\begin{array}{l}\text { Present Perfect } \\
\text { It is late. I am coming }\end{array}$ & Present \\
\hline (47) & $\begin{array}{l}\text { Present Perfect } \\
\text { /hegel ten ketab neve }[\text { te-æst/ } \\
\text { Hegel ten book written-is }\end{array}$ & $\begin{array}{l}\text { Past Simple } \\
\text { Hegel wrote ten books (Note } \\
\text { 3) }\end{array}$ & Past \\
\hline (48) & $\begin{array}{l}\text { Past Simple } \\
\text { /væqti resid-i be mæn begu/ / } \\
\text { when arrived-you to me say }\end{array}$ & $\begin{array}{l}\text { Present Simple } \\
\text { When you arrive let me know. }\end{array}$ & Future \\
\hline (49) & $\begin{array}{l}\text { Present Perfect } \\
\text { /'u goft pærviz-ra dide-'æst/ } \\
\text { (S)he said Parviz-DO marker seen-is }\end{array}$ & $\begin{array}{l}\text { Past Perfect } \\
\text { He said he had seen Parviz. }\end{array}$ & Past \\
\hline (50) & $\begin{array}{l}\text { Present Perfect } \\
\text { /'u fekr mikærd pærviz 'indz-ast/ } \\
\text { (S)he think did Parviz here is }\end{array}$ & $\begin{array}{l}\text { Past Simple } \\
\text { He thought that Parviz was } \\
\text { here. }\end{array}$ & Past \\
\hline
\end{tabular}

\section{Applications}

Unfortunately language textbooks, and consequently EFL (Note 4) teachers do not usually elaborate the significant differences between the two concepts of time and tense. This has resulted in ill-formed sentences and erroneous word-for-word translation in the target language. This research can be of help in Iranian EFL and translator training courses.

\section{Concluding Remarks}

Time and tense are two totally different concepts. While time is a natural or notional concept of language, tense is the relationship between the form of the verb which expresses the time. There is not usually a one-to-one relationship between time and tense within a language. Any language may use the same tense to express different times and vice-versa. On the other hand, there is not a total one-to-one correspondence within different languages. Different languages may employ different tenses to express the same time and vice-versa. Elaboration of these differences, which is usually neglected, plays a very important part in foreign language teaching/learning and translation.

\section{Suggestion for Further Studies}

The focus of this research was mainly on time-tense dichotomy in English and Persian. Other 
pieces of research are suggested to be conducted, with emphasis on other languages.

\section{References}

Baker, M. (2012). In Other Words. Routledge.

Bright, W. (2000). International Encyclopedia of Linguistics. Oxfor University Press.

Comrie, B. (1976). An Introduction to the Study of Verbal Aspect and Related Problems.. Cambridge University Press.

Comrie, B. (1983). Tense (Cambridge Textbooks in Linguistics). Cambridge University Press.

Crystal, D. (1977). The Cambridge Encyclopedic of Language. Cambridge University Press.

Daudet, A. (1977). Tartarin de Tarascon. CLE International.

Delaisne, P., McBride, N., \& Trevisi, S. (1998). Café Crème3, Methode De Français. Hachette Livre.

Dickens, Ch. (1982). David Copperfield, Pingouin Classics.

Dixon, R. J. (1989). Graded Exercises in English. New York. Regents Publishing Co.

Finch. G. (2005). Key Concepts in Language and Linguistics (2nd ed). Palgrave Macmillan.

Hewings, M. (2003). Advanced Grammar in Use. Cambridge University Press.

Hieber, W. (1998). Lernziel Deutsch, Grundstufe2. Max Hueber Verlag.

Jespersen, O. (1924). The Philosophy of Grammar. London: Allen \& Unwin.

Klein, W. (1994). Time in Language. Routledge, London.

Lyons, J. (1968). Introduction to Theoretical Linguistics. Cambridge University Press. http://dx.doi.org/10.1017/CBO9781139165570

Matthews, P. H. (2007). Oxford Concise Dictionary of Linguistics, Oxford University Press.

Quirk, R., \& Greenbaum, S. (1973). A University Grammar of English. London: Longman.

Radford, A. (2006) Minimalist Syntax-Exploring the structure of English. Cambridge Textbooks in Linguistics. Cambridge.

Richards, J. C., \& Schmidt, R. (2002). Dictionary of Language Teaching \& Applied Linguistics. London: Longman.

Scovel, T. (1971). A Look-See at Some Verbs of Perception. Language Learning, 21(1), 75-84. http://dx.doi.org/10.1111/j.1467-1770.1971.tb00491.x

Shaw, H. (1986). McGraw-Hill Handbook of English. McGraw-Hill International Editions

Simpson, J. M. Y. (1984). A First Course in Linguistics. Edinburgh University Press. 


\section{Macrothink}

International Journal of Linguistics

ISSN 1948-5425

2013, Vol. 5, No. 5

Trask, R.L. (1993). A Dictionary of Grammatical Terms in Linguistics. Routledge.

Trask, R.L. (2008). Language and Linguistics, The Key Concepts. Routledge.

\section{Notes}

Note 1. The English, German and French examples are taken from Hewings, M.(2003).

Hieber, W. (1998). and. Delaisne, P., McBride, N. \&Trevisi, S. (1998), respectively.

Note 2. According to Trask (1993), " Sequence of Tenses is the phenomenon, occurring in English and some other languages, by which the tense of a finite verb in a matrix clause constraints on the tense of a finite verb in a complement clause. In English the rule is simply that a past tense in the main clause must be followed by a past tense in the complement clause: Lisa says he wants a BMW; Lisa said the she wanted a BMW; but ?? Lisa said she wants a $B M W "$ (p. 251). "Though this rule does not apply in all other languages, it is an important one in English and should be followed carefully" (Dixon, 1989, p. 96).

Note 3. The sentence " Hegel has written ten books", though grammatical is not acceptable in English, as it implies that Hegel is still alive and can write more books.

Note 4. English as a Foreign Language. 